\title{
PENENTUAN KAWASAN SAWAH BERKELANJUTAN
}

\section{DETERMINATION OF SUSTAINABILITY PADDY FIELDS}

\author{
Ahmad Yazidun Nafi', Yudi Basuki² \\ ${ }^{1}$ Magister Perencanaan Wilayah dan Kota; Universitas Diponegoro, Semarang, Jawa Tengah; ahmadyazidunnafi@gmail.com \\ 2Departemen Perencanaan Wilayah dan Kota; Universitas Diponegoro, Semarang, Jawa Tengah; yudibasuki@yahoo.com
}

\section{Info Artikel:}

- Artikel Masuk: 29 Desember 2018

\begin{abstract}
ABSTRAK
Alih fungsi lahan pertanian ke non pertanian menjadi permasalahan di kawasan pinggiran perkotaan. Alih fungsi lahan ini disebabkan land rent lahan pertanian tidak menguntungkan dibandingkan jika dibandingkan dengan lahan komersil. Jika kondisi ini terus berlanjut maka akan mengancam ketahanan pangan suatu wilayah. Penelitian ini bertujuan untuk memodelkan penentuan kawasan sawah berkelanjutan berdasarkan analisis spasial dan teknik penginderaan jauh. Analisis yang digunakan meliputi analisis interpretasi citra, Geography Information System (GIS), analisis statistik, dan analisis prediksi ketersediaan lahan sawah. Penelitian ini dilakukan di Kabupaten Semarang dengan perkembangan perkotaan yang cepat. Variabel dalam menyusun model kawasan sawah berkelanjutan ini terdiri dari variabel produktivitas padi, kesesuaian lahan pertanian, intensitas panen, dan serta proyeksi arah perkembangan perkotaan. Hasil analisis produktivitas tanaman menghasilkan persamaan statistik produktiivtas $(\mathrm{Ton} / \mathrm{Ha})=3,795(\mathrm{NDVI})+3,773$ dan nilai koefisiennya sebesar 0,85. Terdapat selisih antara data dinas dengan data peneliti sebesar $10 \%$ dari luas lahan pertanian eksisiting. Selisish luas ini dikarenakan perbedaan skala peta, proses analisis, dan metode yang digunakan. Berdasarkan hasil analisis dan pembahasan maka dapat disimpulkan bahwa lahan sawah berkelanjutan ketersediannya mulai berkurang. Sehingga perlu adanya ketegasan pemerintah daerah dalam menjaga ketersedian lahan sawah.
\end{abstract}

Kata Kunci : Pemodelan Spasial, Sawah Berkelanjutan, Prediksi Guna Lahan

\begin{abstract}
Conversion of paddy field into non agricultural problems in the urban fringe areas. Conversion of land due to land rent farmland unprofitable compared when compared to land commercial. If this condition continues, it will threaten the food security of a region. This research was conducted to model sustainable paddy field zone based on the spatial analysis and remote sensing techniques. The analysis used include image interpretation analys, Geography Information System (GIS), statistical analysis, predictive analysis and availability of paddy fields. This research was conducted in Semarang Regency with urban development. Variables in developing a sustainable rice field model consist of variable productivity of paddy fields, land suitability, harvest intensity, and predict directions for urban development. The results of the analysis of productivity of plants produce statistical equations productivity $(T o n / H a)=3,795$ (NDVI) $+3,773$ and the value of the coefficient of 0.85 . There is a difference between official data and researchers' data of $10 \%$ of the area of existing agricultural land. This wide difference is due to differences in map scale, process analysis, and methods used. Based on the results of the analysis and discussion, it can be concluded that sustainable wetland availability is decreasing. So, there needs to be a firmness of the local government in maintaining the availability of paddy fields.
\end{abstract}

Keyword: Spatial Modelling, Sustainability Paddy Field, Landuse Predict

Copyright $\odot$ 2019JPWK UNDIP This open access article is distributed under a Creative Commons Attribution (CC-BY-NC-SA) 4.0 International license.

\section{PENDAHULUAN}

Alih fungsi lahan pertanian ke non pertanian yang tidak sesuai peruntukannya menjadi permasalahan dalam penataan ruang (Raziq, dkk., 2016). Permasalahan tersebut timbul karena rendahnya land rent lahan pertanian jika dibandingkan dengan penggunaan lahan komersil. Sedangkan peraturan daerah tentang Rencana Tata Ruang Wilayah (RTRW) dan Lahan Pertanian Lahan Pangan Berkelanjutan (LP2B) belum efektif 
dalam mengehentikan alih fungsi lahan sawah. Kondisi ini terlihat dengan adanya penurunan luas sawah sebesar 86,12 hektar dalam 5 tahun terakhir. Dampak dari penurunan ini akan berdampak pada ketahanan pangan di pinggiran kawasan perkotaan (Naab, dkk., 2013). Kabupaten Semarang merupakan salah satu wilayah yang memiliki lokasi yang strategis di Provinsi Jawa Tengah. Wilayah ini berada pada dua pusat perkembangan perkotaan, yaitu Kota Semarang dan Kota Surakarta. Dengan mayoritas penduduk bermata pencarian sebagai petani. Sektor pertanian dan industri menyumbang pendapatan tertinggi di wilayah ini (BPS, 2016). Namun yang menjadi permasalahan di kabupaten ini adalah sulitnya melakukan perlindungan alih fungsi lahan pertanian ke kawasan non pertanian. Alih fungsi lahan di wilayah ini disebabkan adanya perkembangan Kota Semarang dan perkembangan Kabupaten Semarang itu sendiri.

Pembuatan Peraturan Daerah tentang Rencana Tata Ruang Wilayah (RTRW) merupakan salah cara yang sering dilakukan pemerintah dalam mengatasi alih fungsi lahan pertanian. Namun dalam prakteknya sering terjadi ketidaksesuaian antara RTRW dengan kondisi eksisting suatu wilayah. Perubahan alih fungsi lahan merupakan suatu dinamika yang sangat cepat terjadi, terutama di kawasan yang memiliki nilai strategis. Dalam menghadapi dinamika tersebut, maka diperluhkan suatu teknik pemodelan yang dapat memonitoring alih fungsi lahan tersebut. Selain pemodelan juga membutuhkan skenario kebijakan (Santosa et al., 2014)(Huang, 2015). Pemanfaatan data remote sensing (RS) dan geographic information system (GIS) hadir untuk menjawab tantangan dinamika alih fungsi lahan yang begitu cepat. Manfaat penggunaan RS dan GIS ini adalah dapat menghasilkan informasi data secara spasial secara cepat, hemat, akurat, dan efisien. Penggunaan teknik ini dapat digunakan sebagai alat yang paling efektif dalam memonitoring lahan pertanian (Liaghat \& Balasundram, 2010)(Widiatmaka, dkk., 2014) (Widiatmaka, dkk., 2016). Indikator dalam kesuksesan tata ruang dapat dilihat dari minimnya alih fungsi lahan sawah ke kawasan terbangun.

Terdapat beberapa penelitian sebelumnya mengenai penentuan lahan sawah. Misalnya Noureldin et al., (2013) tentang pemodelan hasil tanaman padi menggunakan citra satelit di Mesir. Santosa et al., (2014) mengenai pemodelan penetapan lahan sawah berkelanjutan di Kabupaten Sukabumi. Selain itu, Song et al., (2015) dinamika perubahan lahan sawah akibat urbanisasi di Hang Jia Hu. Namun, belum adanya penelitian yang menghubungkan antara analisis remote sensing, GIS, dan penataan ruang sehingga menghasilkan penentuan kawasan sawah berkelanjutan yang sesuai dengan analisis hasil proyeksi penggunaan lahan kedepan. Sehingga, penggunaan analisis spasial dan penataan ruang mengenai penentuan kawasan sawah berkelanjutan ini penting untuk dilakukan.

Penelitian ini bertujuan untuk merancang model kawasan sawah berkelanjutan dengan memanfaatkan metode indek vegetasi dan prediksi landuse cover Kabupaten Semarang. Penelitian ini bermanfaat sebagai bahan masukan dalam mempermudah pengambilan keputusan dan kebijakan penentuan kawasan sawah berkelanjutan. Manfaat lebih jauhnya, penelitian ini dapat digunakan sebagai dasar penyusunan rencana pola ruang dalam RTRW. Pemodelan ini disusun berdasarkan variabel-variabel yang sangat berkaitan secara langsung maupun prediksi dimasa depan.

\section{DATA DAN METODE}

Penelitian ini berlokasi di Kabupaten Semarang yang merupakan salah satu kabupaten di Provinsi Jawa Tengah. Wilayah ini berada pada lokasi yang strategis karena berada pada pusat kegiatan wilayah Kota Semarang dan kota Surakarta. Wilayah ini terdiri dari 19 kecamatan dengan luas 95.020,64 hektar atau setara 2,92\% luas Provinsi Jawa Tengah. Penggunaan lahan terdiri dari lahan pertanian dan non pertanian. Lahan pertanian memiliki luas 60.276 hektar atau $63 \%$ dari luas wilayah.

Pertumbuhan ekonomi Kabupaten Semarang didominasi oleh sektor industri dan pertanian. Pola persebaran industri berada pada jaringan jalan arteri di Kecamatan Bawen. Sedangkan pola persebaran lahan pertanian tersebar di semua kecamatan. Dalam menunjang lahan pertanian terdapat 4 pembagian sistem jaringan pengairan. Dengan adanya jaringan tersebut, maka menciptakan lahan sawah irigasi seluas 11107,93 hektar. Lokasi penelitian dapat dilihat pada Gambar 1 dan sedangkan diagram alir penelitian dapat dilihat pada Gambar 2. Diagram penelitian berisi alur pemikiran dalam pengerjaan penelitian ini. Diagram ini 
Nafi, Basuki/ Jurnal Pembangunan Wilayah dan Kota, Vol.15, No.3, 2019

Doi: https://doi.org/10.14710/pwk.v15i3.21570

dimulai dari masukan data yang kemudian dilakukan proses analisis yang menghasilkan keluaran berupa lahan sawah berkelanjutan. Setelah menghasilkan data tersebut kemudian dilakukan validasi hasil penelitian.



Sumber: Hasil Analisis, 2018

Gambar 1. Lokasi Penelitian

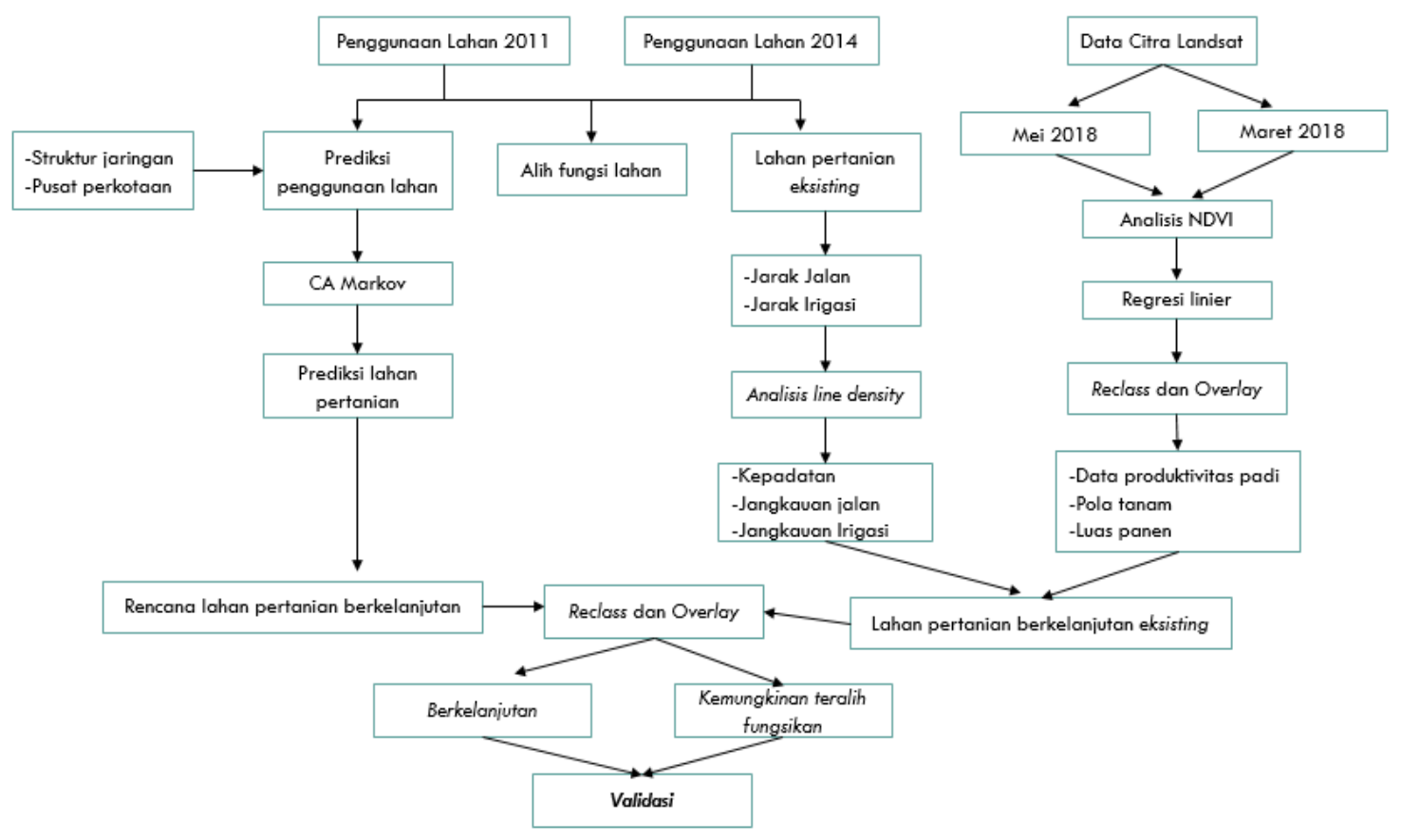

Sumber: Hasil Analisis, 2018

Gambar 2. Diagram Penelitian

Dalam menyusun penelitian ini, peneliti menentukan variabel-variabel yang sesuai dengan kondisi fisik lahan sawah di Kabupaten Semarang. Variabel tersebut meliputi produktivitas tanaman padi 
menggunakan indek vegetasi, perubahan guna lahan secara time series, infrastruktur dasar jalan dan sungai, kemampuan lahan, serta prediksi perkembangan ketersediaan lahan sawah di masa depan. Sedangkan data yang digunakan meliputi data citra satelit Landsat 7 dan 8 dengan perekamaan tahun 2011, 2014, dan 2018 pada Path 120 dan Row 65, data spasial jaringan jalan dan irigasi, data spasial LP2B dan RTRW Kabupaten Semarang, data statistik produksi, pola tanam, serta data jumlah penduduk. Sedangakan dalam menganalisis data menggunakan software ArcGIS 10.3, ENVI 5, LanduseSim, dan Microsoft office. Data yang diolah berformat shapefile (shp), citra satelit (tif), dan data excel (xls). Penelitian ini menggunakan empat teknik analisis, yaitu analisis interpretasi citra satelit, analisis Geography Information System (GIS), analisis statistik, dan analisis prediksi ketersediaan lahan sawah.

Pertama, analisis interpretasi citra dapat dilakukan menggunakan foto udara, foto satelit ataupun menggunakan data digital yang dapat ditampilkan dalam bentuk gambar. Penggunaan analisis ini dalam penelitian adalah dengan menggunakan metode transformasi citra. Transformasi merupakan suatu cara untuk menonjolkan pixel untuk mendapatkan suatu informasi data tertentu. Salah satu bentuk penerapan dari metode ini adalah analisis Normalized Different Vegetation Index (NDVI) yang dikombinasikan dengan klasifikasi penggunaan lahan pertanian (Mosleh et al., 2015). Penggunaan NDVI dan data produktivitas tanaman ini akan menghasilkan data tentang produktivitas tanaman berdasarkan Digital Number (DN) suatu citra. DN tersebut memberikan informasi tentang kondisi tanaman. Nilai NDVI hanya berkisar antara -1 sampai 1. Penggunaan regresi linier sederhana dapat digunakan untuk mengestimasi produktivitas tanaman padi (Rahman et al., 2009) (Nafi et al., 2016). Rumus regresi linier sederhana disajikan pada Persamaan 1. Setelah mendapatkan persamaan maka selanjutnya dilakukan pengkelasan berdasarkan nilai piksel. Pengkelasan hubungan NDVI dan umur tanaman padi tersaji dalam Tabel $\mathbf{1}$

$$
\mathrm{Y}=\mathrm{ax}+\mathrm{b} \text {. }
$$

dimana:

$$
\begin{aligned}
& \mathrm{y}=\text { nilai produktivitas tanaman } \\
& \mathrm{a}=\text { konstanta } \\
& \mathrm{x}=\mathrm{NDVI} \\
& \mathrm{b}=\text { konstanta } \mathrm{b}
\end{aligned}
$$

Tabel 1. Hubungan NDVI dan Umur Tanaman Padi

\begin{tabular}{cclc}
\hline Kelas & Kelas NDVI & Tingkat kehijauan/ kondisi lahan & $\begin{array}{c}\text { Umur tanaman } \\
(\text { MST })\end{array}$ \\
\hline 1 & $<-0,03$ & Tidak bervegetasi/terbuka/air & $<3$ \\
2 & $-0,03$ s/d 0,15 & Kehijauan sangat rendah & $3-<4$ \\
3 & 0,15 s/d 0,25 & Kehijauan rendah & $4-6$ \\
4 & 0,26 s/d o,35 & Kehijauan sedang & $6-8$ \\
5 & 0,35 s/d o,61 & Kehijauan tinggi & $8-13$ \\
\hline
\end{tabular}

Sumber: Wahuyunto dalam Nafi, 2016

Keterangan: Setelah vegetatif optimum nilai NDVI akan turun Sesuai dengan tingkat kematangan bulir

Kedua, analisis GIS dimanfaatkan untuk mengolah data yang berformat shapefile (shp). Salah satu model analisisnya adalah teknik overlay dan reclass dari beberapa data shp. Hasil dari ketiga analisis ini akan menghasilkan sutau deliniasi lahan sawah memiliki kriteria lahan sawah berkelanjutan yang kemudian di lakukan survei lapangan sebagai hasil verifikasi penelitian. Ketiga, analisis statistik merupakan suatu analisis untuk mengolah data-data numerik. Analisis ini sangat bermanfaat untuk mengolah hasil dari analisis interpretasi citra, analisis SIG serta data statistik. Hasil dari analisis ini dapat berupa deskriptif dan penyajian data berupa tabel, diagram, ataupun gambar. Dari setiap analisis yang telah dibuat maka dibuat deskripsi yang menjelaskan hasil yang diperoleh. Keempat, analisis prediksi ketersedian lahan sawah yang bertujuan 
untuk mendapatkan gambaran mengenai alih fungsi lahan dimasa depan. Variabel dalam menentukan prediksi ketersedian lahan sawah ini terdiri dari variabel jarak antar lahan sawah dengan jaringan jalan, irigasi, pusat perkotaan, perdagangan jasa, industri, dan permukiman. Penggunaan data satelit Landsat tahun 2007 dan 2013 dapat digunakan untuk memodelkan prediksi alih fungsi lahan. Sedangkan sebagai hasil validasi dari model yang dibuat adalah menggunakan citra Landsat tahun 2018.

\section{HASIL DAN PEMBAHASAN}

\subsection{Analisis Produktivitas Padi}

Nilai indek vegetasi dengan menggunakan metode NDVI dapat digunakan untuk mengestimasi hasil produktivitas tanaman padi. Pemanfaatan saluran merah dan saluran infra merah dapat mencerminkan tingkat kerapatan tanaman padi. Hubungan antara NDVI dengan produktivitas tanaman padi dapat dilihat pada Grafik 1.

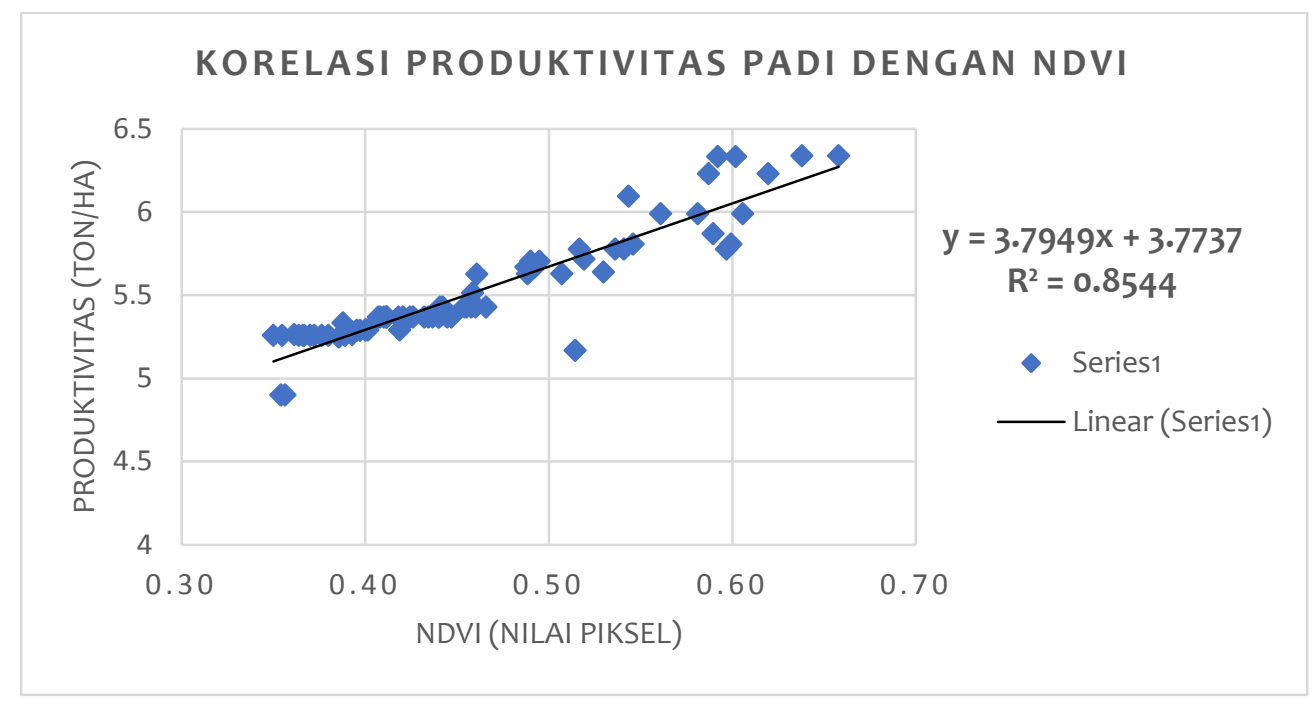

Sumber: Hasil Analisis, 2018

Grafik 1. Hubungan NDVI dengan Produktivitas Tanaman Padi

Pada grafik tersebut menunjukan hubungan yang signifikan. Persamaan tersebut menghasilkan persamaan statistik produktiivtas (Ton/Ha) =3,795 (NDVI) + 3,773 dan nilai koefisiennya sebesar 0,85. Grafik tersebut juga menunjukan sebesar $85 \%$ NDVI berkontribusi dalam nilai produktivitas tanaman padi dan $15 \%$ adalah faktor lain. Data produktivitas ini merupakan salah satu variabel yang penting dalam menentukan lahan sawah berkelanjutan. Pemanfaatan teknik penginderaan jauh sangat bermanfaat untuk menghasilkan data yang cepat, hemat pembiayaan, akurat, serta sangat efisien. Pemilihan jenis tanaman dikarenakan sawah yang ada di Pulau Jawa sangat didominasi oleh tanaman padi dengan pola panen antara sekali sampai tiga kali panen. Estimasi produktivitas tanaman padi disajikan dalam Tabel 2.

Berdasarkan Tabel 2 merupakan hasil pengolahan citra satelit menggunakan analisis NDVI. Hasil analisis tersebut dibagi menjadi 4 kelas yaitu kelas bukan sawah, kehijauan rendah, kehijauan sedang, dan kehijauan tinggi. Berdasarkan kelas tersebut kemudian dilakukan analisis berupa estimasi umur tanaman, produktivitas, dan produksi tanaman di lahan sawah. Pada tabel tersebut didominasi oleh tingkat kehijauan tinggi menjelaskan kondisi lahan sawah pada masa panen dengan estimasi produksi 103.513,70 ton. Sedangkan kelas bukan sawah dapat di interpretasikan sebagai penggunaan lahan permukiman, perkebunan, hutan, sungai, danau, dan lain-lain. Pola perkembangan tanaman padi berdasarkan regresi linier yang dimobinasikan dengan metode NDVI tersaji pada Gambar 3. 
Nafi, Basuki/ Jurnal Pembangunan Wilayah dan Kota, Vol.15, No.3, 2019

Doi: https://doi.org/10.14710/pwk.v15i3.21570

Tabel 2 Estimasi Produktivitas Tanaman Padi

\begin{tabular}{|c|c|c|c|c|c|c|}
\hline No & Kelas & Luas (Ha) & $\begin{array}{c}\text { Luas } \\
\text { Sawah } \\
\text { (Ha) }\end{array}$ & $\begin{array}{c}\text { Umur } \\
\text { (Minggu) }\end{array}$ & $\begin{array}{l}\text { Produktivitas } \\
\text { (Ton/Ha) }\end{array}$ & $\begin{array}{l}\text { Produksi } \\
\text { (Ton) }\end{array}$ \\
\hline 1 & Bukan Sawah & $77.446,32$ & - & - & - & - \\
\hline 2 & Kehijauan Rendah & $2.016,95$ & 25177.03 & $4-6$ & 4,62 & $9 \cdot 308,21$ \\
\hline 3 & Kehijauan Sedang & $4.502,24$ & & $6-8$ & 5,05 & $22.736,30$ \\
\hline 4 & Kehijauan Tinggi & $18.657,84$ & & $8-13$ & 5,55 & $103 \cdot 513,70$ \\
\hline \multicolumn{7}{|c|}{ Rerata Produktivitas $=5,07$ Ton $/ \mathrm{Ha}$} \\
\hline
\end{tabular}

Sumber: Hasil Analisis, 2018
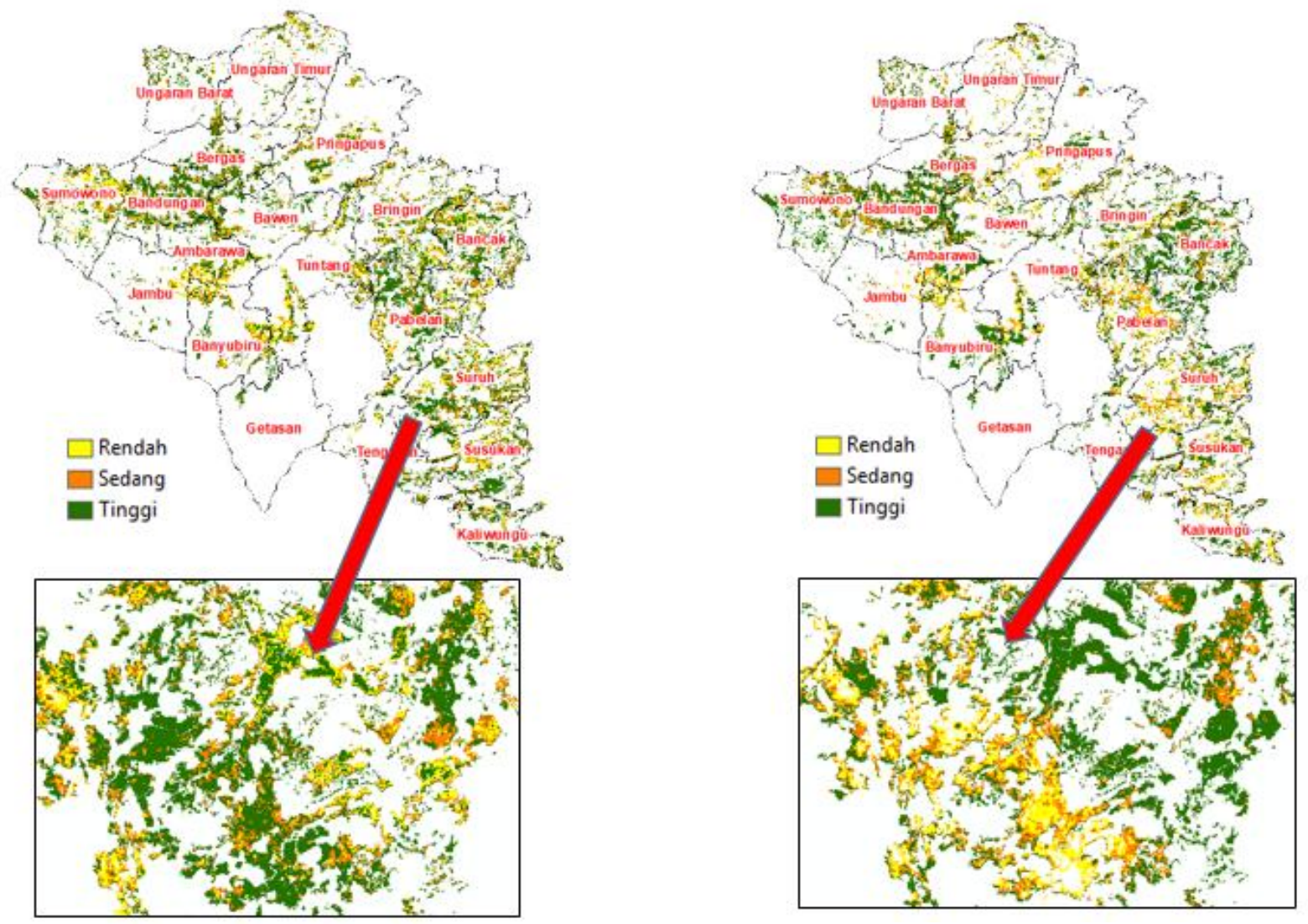

Sumber: Hasil Analisis, 2018

Gambar 3. Pola Perkembangan Tanaman Padi

\subsection{Analisis Kesesuaian Lahan Pertanian}

Kemampuan lahan merupakan potensi yang dimiliki suatu lahan untuk dimanfaatkan sebagai lahan pertanian secara umum, sedangkan kesesuaian lahan merupakan potensi yang dimiliki suatu lahan untuk dimanfaatkan sesuai jenis tanaman tertentu (Widiatmaka et al., 2014). Analisis ini disusun berdasarkan beberapa variabel yang kemudian dilakukan overlay data. Variabel tersebut terdiri dari curah hujan, hidrogeologi, jenis tanah, kelerengan, rawan banjir, jaringan jalan, dan jaringan drainase.

Kabupaten Semarang memiliki curah hujan yang tergolong tinggi. Curah hujan yang terjadi antara rentang 1.500 sampai lebih dari $3.000 \mathrm{~mm}$ pertahun. Dengan intensitas yang tinggi ini membuat berbagai 
Nafi, Basuki/ Jurnal Pembangunan Wilayah dan Kota, Vol.15, No.3, 2019

Doi: https://doi.org/10.14710/pwk.v15i3.21570

jenis tanaman dapat tumbuh subur di kabupaten ini. Faktor intensitas curah hujan ini berpengaruh terhadap periode masa panen. Jenis tanah di Kabupaten Semarang didominasi oleh jenis alluvial dan latosol yang sangat sesuai jika digunakan sebagai media tanam tanaman. Karena jenis tanah ini cenderung dapat menyimpan air. Variabel pendukung lainnya adalah daerah rawan bencana banjir. Lahan sawah yang berada di kawasan rawan banjir terletak di sekitar jairngan irigasi yang berdekatan dengan Rawa Pening. Rawan banjir dimasukan dalam variabel kesesuaian lahan dikarenakan kawasan tersebut sering mengalami beberapa gagal panen dalam setahun.

Tabel 3. Kesesuaian Lahan Pertanian

\begin{tabular}{llrr}
\hline No & \multicolumn{1}{c}{ Kesesuaian Lahan } & Luas (Ha) & $\%$ \\
\hline $\mathbf{1}$ & Sangat sesuai (S1) & $20.511,51$ & $81,4 \%$ \\
$\mathbf{2}$ & Sesuai (S2) & $4.272,64$ & $17,0 \%$ \\
$\mathbf{3}$ & Sesuai bersyarat (S3) & 396,91 & $1,6 \%$ \\
$\mathbf{4}$ & Tidak sesuai (N) & 9,48 & $0,0 \%$ \\
\hline \multicolumn{2}{l}{ Sumber: Wahyunto dalam Nafi, 2016 } &
\end{tabular}

Hasil analisis kesesuaian lahan menghasilkan empat tipologi. Tipologi tersebut terbagi menjadi sangat sesuai (S1), sesuai (S2), sesuai bersyarat (S3), dan tidak sesuai (N). Secara spasial bahwa Kabupaten Semarang merupakan lahan yang sangat sesuai untuk digunakan sebagai lahan pertanian. Lahan yang sangat sesuai berada pada kawasan yang cenderung datar dan memiliki cadangan air yang melimpah.

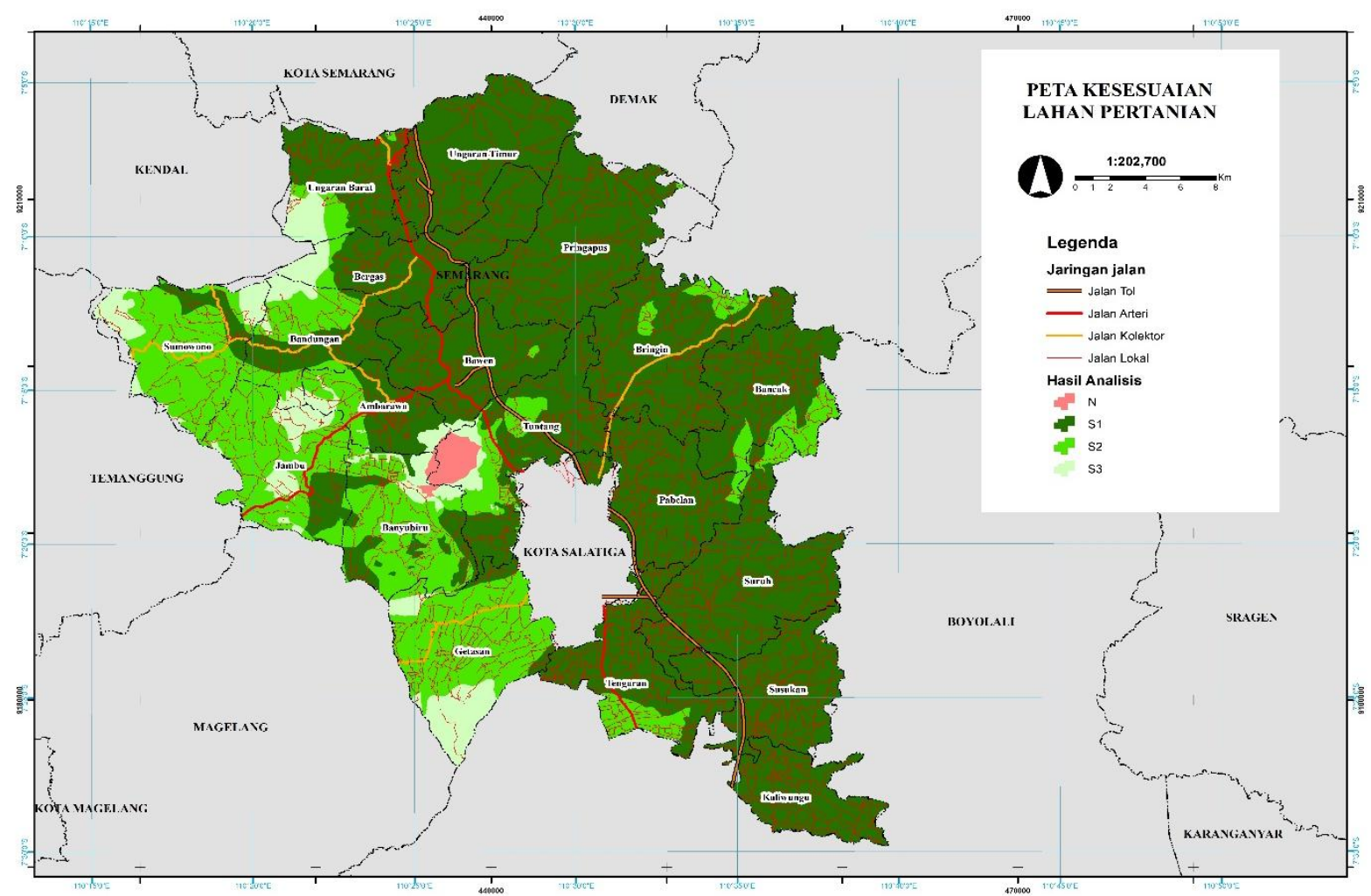

Sumber: Hasil Analisis, 2018

\subsection{Analisis Intensitas Panen}

Gambar 4. Kesesuaian Lahan Pertanian

Total produksi merupakan hasil perkalian dari rerata produktivitas dengan intensitas panen. Kebanyakan petani dapat melakukan 2 kali panen tanaman padi dalam setahun. Menurut Wahyunto, 2006 bahwa porsi intensitas panen 2 kali panen memiliki skor yang lebih tinggi untuk dijadikan lahan pertanian 
Nafi, Basuki/ Jurnal Pembangunan Wilayah dan Kota, Vol.15, No.3, 2019

Doi: https://doi.org/10.14710/pwk.v15i3.21570

berkelanjutan. Hasil pertanian padi dan jumlah produksi berpengaruh terhadap produktivitas padi (Ashidqi \& Taryono, 2017). Hasil produksi terbanyak berada pada Kecamatan Suruh dengan estimasi hasil 23.700,29 ton pertahun. Sedangkan Kecamatan Jambu mempunyai hasil produksi yang terendah yaitu sebesar 4.560,45 ton pertahun. Hasil produksi ini bergantung pada luasan sawah eksisting di masing-masing kecamatan. Pada tahun 2018 Kabupaten Semarang dapat menghasilkan 234.170,32 ton.

Hasil penelitian kemudian dibandingkan dengan hasil produksi padi sawah berdasarkan data dari badan pusat statistik (BPS) Kabupaten Semarang. Berdasarkan data luas panen, produktivitas, dan produksi tanaman padi sawah tahun 2016 diperoleh hasil 237.519,83 ton. Terdapat selisih 3.349,51 ton lebih besar dibandingkan hasil yang diperoleh dari penelitian ini. Hal tersebut dikarenakan perbedaan metode dalam memperoleh data produksi. Data dari BPS berdasarkan perkiraan mantri desa (Wahyunto et al., 2006). Sedangkan data dari penelitian ini berdasarkan analisis spasial dan penginderaan jauh. Peta intensitas panen tanaman padi disajikan dalam Gambar 5.

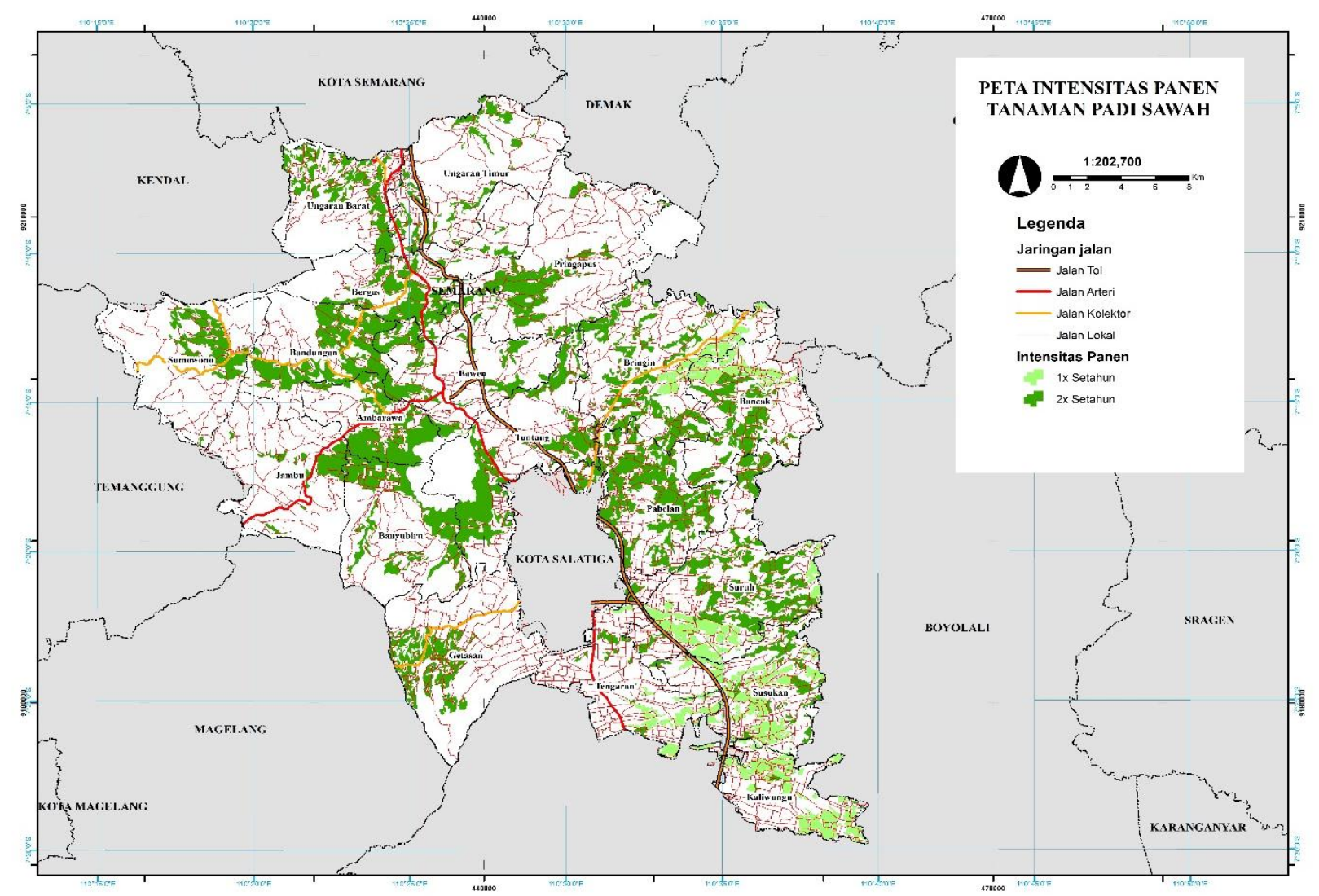

Sumber: Hasil Analisis, 2018

Gambar 5. Peta Intensitas Panen

\subsection{Analisis Kepadatan Jaringan Jalan dan Irigasi}

Analisis kepadatan jaringan jalan dan sungai digunakan untuk mengetahui jangkauan pelayanan yang akan berakibat pada perkembangan kawasan permukiman. Dengan adanya suatu akses jaringan ke suatu wilayah, maka akan menimbulkan perkembangan kawasan terbangun disepanjang jaringan jalan tersebut. Hal ini dapat dilihat pada kondisi kawasan sekitar Pintu Tol Ungaran. Kawasan tersebut sebelum adanya pintu tol masih berupa lahan sawah yang subur, namun ketika pusat perekonomian dan ditambah adanya pintu tol menyebabkan kawasan tersebut beralih fungsi menjadi kawasan perumahan dan perdagangan jasa. Hasil analisis pemodelan kepadatan jaringan jalan dan sungai disajikan dalam Gambar 6. 

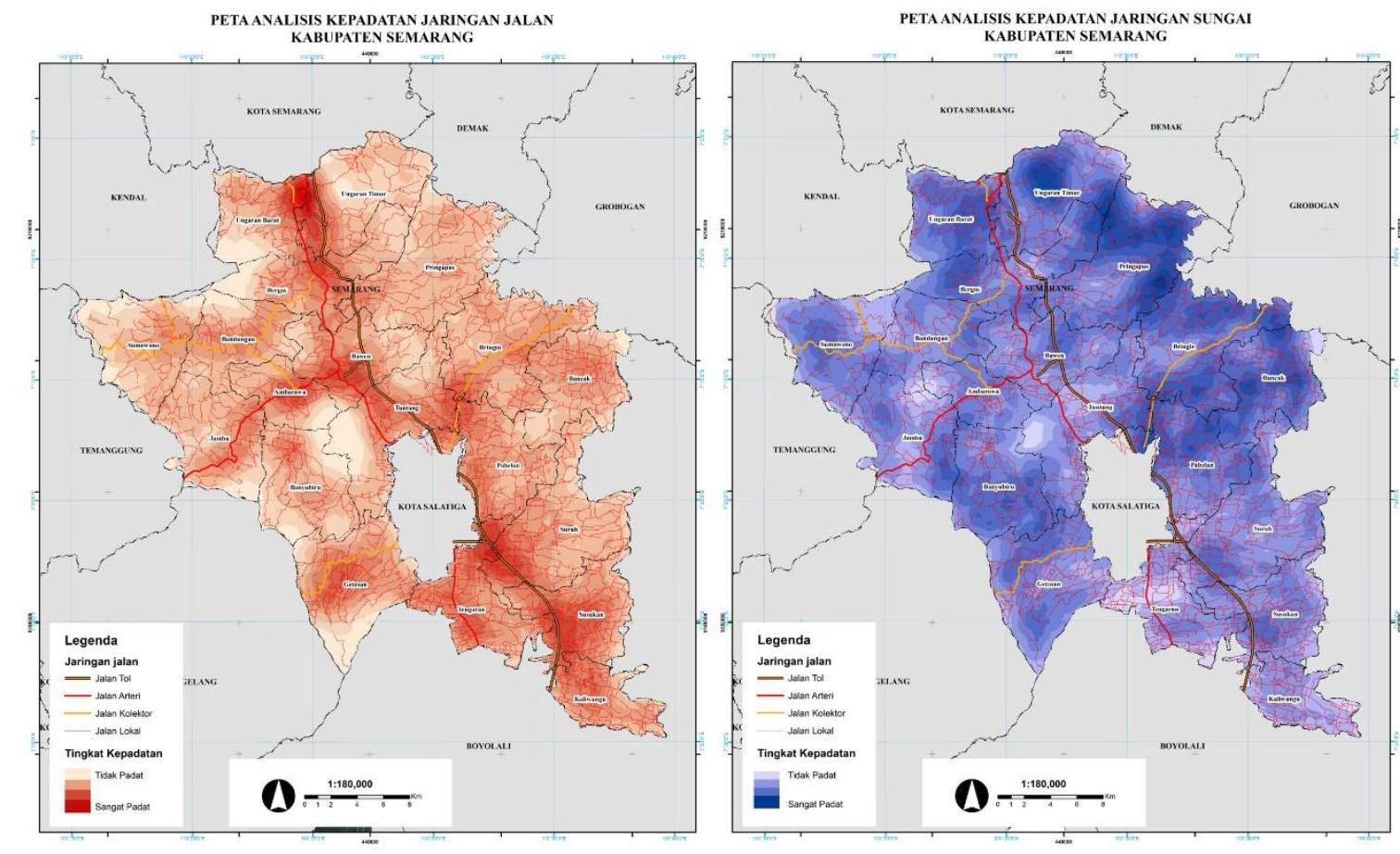

Sumber: Hasil Analisis, 2018

\section{Gambar 6. Pemodelan Jaringan Jalan (kiri) dan Irigasi (kanan)}

Salah faktor yang dapat mempengaruhi produksi padi yaitu adanya saluran irigasi (Panuju et al., 2013). Sistem jaringan sungai berperan dalam menyediakan irigasi untuk lahan pertanian. Jaringan sungai bersumber dari Gunung Ungaran yang kemudian mengalir ke berbagai arah. Arah utara mengalir melalui Sungai Kali Garang yang mengairi Kecamatan Ungaran Barat dan Ungaran Timur. Sedangkan ke arah selatan mengalir ke Rawa Pening. Lahan-lahan pertanian yang dialiri oleh jaringan sungai ini cenderung berupa lahan sawah dengan sistim irigasi teknis. Penggunaan analisis distance operator dapat digunakan untuk memodelkan jangkauan pelayanan jaringan jalan dan irigasi (Santosa et al., 2014).

\subsection{Prediksi Penggunaan Lahan Tahun 2028}

Analisis prediksi penggunaan lahan bertujuan untuk mengetahui pemanfaatan ruang yang terjadi dimasa depan dengan memanfaatkan proyeksi penggunaan lahan dan lokasi cepat tumbuh pada tahun sebelumnya. Dengan mengetahui pemanfaatan ruang di masa depan dapat digunakan untuk menghitung ketersediaan ruang. Mengingat konversi lahan pertanian sulit untuk dihindari, namun dampak yang ditimbulkan bersifat permanen, kumulatif, dan progresif (Irawan, 2005). Pemodelan tentang prediksi penggunaan lahan telah digunakan pada pemodelan berbasis kecenderungan (trend), pertumbuhan perkotaan, dan pemodelan habitat (Mas et al., 2014). Hasil prediksi lahan sawah tahun 2028 menunjukan alih fungsi lahan menjadi kawasan terbangun dan non terbangun. Kawasan terbangun terdiri dari kawasan industri dan permukiman. sedangkan kawasan non terbangun terdiri dari kebun, sawah, tegalan, padang rumput, hutan, danau, dan sungai. 
Nafi, Basuki/ Jurnal Pembangunan Wilayah dan Kota, Vol.15, No.3, 2019

Doi: https://doi.org/10.14710/pwk.v15i3.21570

Tabel 4. Transformasi Penggunaan Lahan Tahun 2018 ke 2028

\begin{tabular}{|c|c|c|c|c|c|}
\hline \multicolumn{4}{|c|}{ Penggunaan Lahan } & \multirow{2}{*}{ Perkembangan (Ha) } & \multirow{2}{*}{ (\%) } \\
\hline Tahun 2018 & Luas (Ha) & Tahun 2028 & Luas (Ha) & & \\
\hline Danau/Situ & $1.531,68$ & Danau/Situ & $1.537,58$ & 5,90 & $0,4 \%$ \\
\hline Hutan & $1.583,26$ & Hutan & $1.588,48$ & 5,22 & $0,3 \%$ \\
\hline Industri & 240,74 & Industri & 267,49 & 26,75 & $53,1 \%$ \\
\hline Padang Rumput & $3.999,01$ & Padang Rumput & $4.002,72$ & 3,71 & $0,1 \%$ \\
\hline Perkebunan/Kebun & $33.911,01$ & Perkebunan/Kebun & $33.864,04$ & $-46,97$ & $-0,1 \%$ \\
\hline Permukiman & $18.207,60$ & Permukiman & $19 \cdot 322,49$ & $1.114,89$ & $6,7 \%$ \\
\hline Sawah & $25.183,96$ & Sawah & $24.195,87$ & $-988,09$ & $-3,8 \%$ \\
\hline Sungai & 384,08 & Sungai & 394,37 & 10,30 & $2,7 \%$ \\
\hline Tegalan/Ladang & $14 \cdot 754,32$ & Tegalan/Ladang & $14.638,69$ & $-115,63$ & $-0,8 \%$ \\
\hline Waduk & 1,62 & Waduk & 1,63 & 0,01 & $0,7 \%$ \\
\hline Jumlah (Ha) & $99.797,27$ & & $99 \cdot 797,27$ & & \\
\hline
\end{tabular}

Sumber: Hasil Analisis, 2018

Lahan sawah mengalami penurunan setiap tahun, dengan rata-rata penurunan sekitar 93,9 Ha setiap tahunnya. Sedangkan lahan permukiman bertambah sekitar 111,4 Ha setiap tahun. Pola alih fungsi lahan di Kabupaten Semarang didasarkan dari kawasan perkotaan dan kawasan perdesaan. Pada kawasan perkotaan cenderung melakukan alih fungsi lahan disekitar jaringan jalan primer dan mendekati pusat pertumbuhan kota. Sedangkan kawasan permukiman perdesaan cenderung melakukan perkembangan secara mengelompok. Hasil prediksi penggunaan lahan disajikan secara spasial pada Gambar 7. Pertumbuhan di tiga kecamatan tersebut didominasi oleh kawasan perdagangan jasa, permukiman, dan perumahan. Pertumbuhan ini mempunyai pola mengikuti jaringan jalan. Kawasan yang berada di pinggir jaringan jalan arteri dan kolektor didominasi oleh perdagangan dan jasa dan sedangkan kawasan yang berada di jalan lokal cenderung berubah menjadi kawasan permukiman. Sedangkan Kecamatan Tengaran, Jambu, dan Tuntang merupakan wilayah yang memiliki rata-rata alih fungsi lahan paling sedikit.

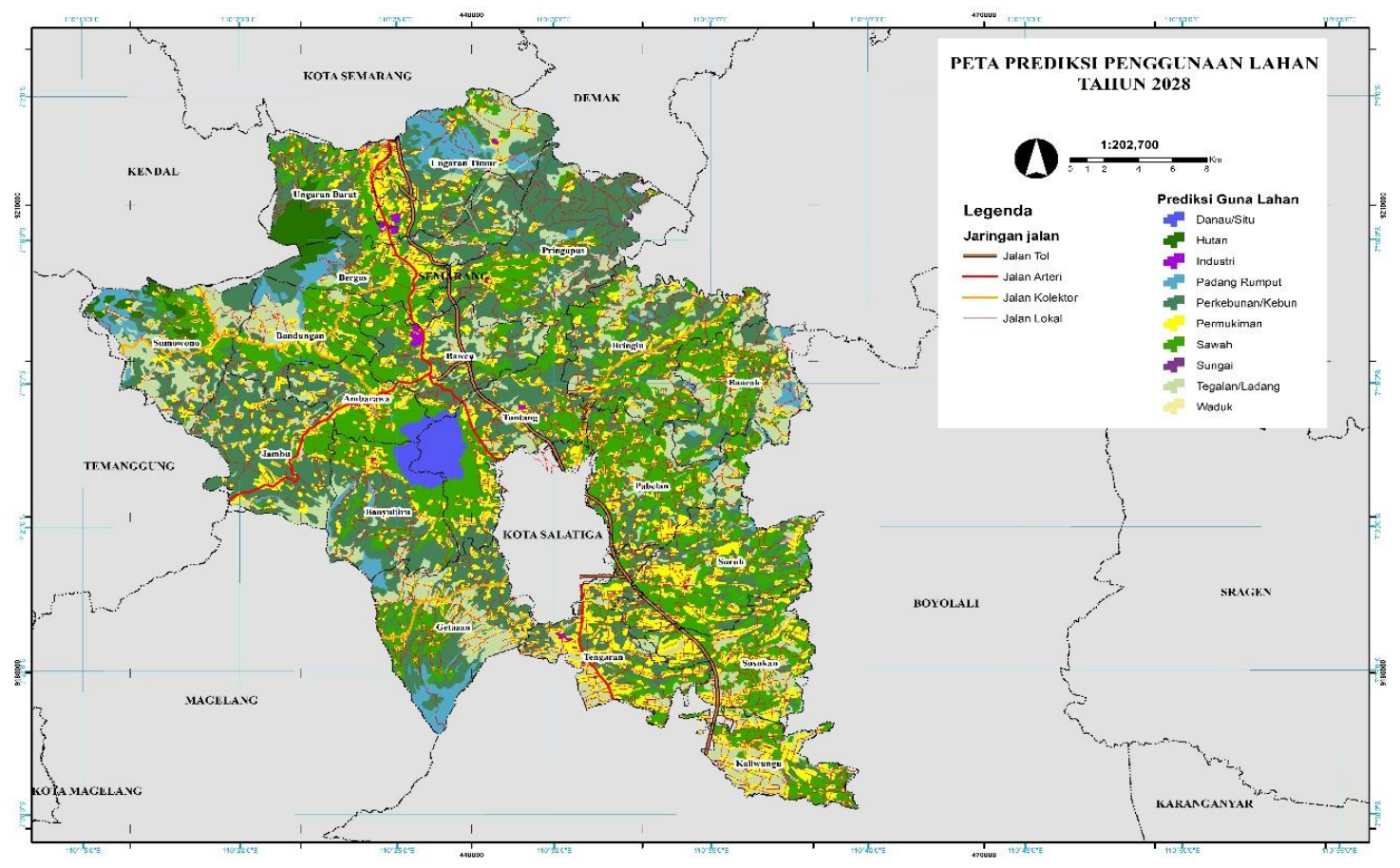

Sumber: Hasil Analisis, 2018

Gambar 7. Peta Prediksi Penggunaan Lahan Tahun 2028 
Analisis prediksi penggunaan lahan pertanian tahun 2028 terdiri dari perkebunan (33.864,04 ha), sawah (24.195,87 ha), dan tegalan (14.638,69 ha). Pada tahun tersebut di prediksi terjadi penurunan luas lahan sawah sebesar 988,09 ha dalam waktu 10 tahun kedepan. Kawasan non terbangun terdiri dari kawasan kebun, sawah, tegalan, danau, waduk, padang rumput, dan sungai. Perubahan sawah paling dominan terjadi pada kawasan kebun. Secara total terjadi perubahan sebesar 226,13 Ha. Kecamatan Suruh dan Bringin merupakan wilayah yang banyak terjadi alih fungsi lahan tersebut. Pada kondisi saat ini, di kedua kecamatan tersebut lebih didominasi oleh perkebunan karet.

\subsection{Penetapan Kawasan Sawah Berkelanjutan (KSB)}

Penetapan lahan sawah berkelanjutan pada penelitian ini didasarkan dari berbagai analisis secara spasial. Analisis tersebut terdiri dari analisis proyeksi penduduk, analisis produktivitas tanaman, analisis kepadatan jaringan jalan dan irigasi, analisis kesesuaian lahan pertanian, serta analisis prediksi penggunaan lahan tahun 2028. Berdasarkan analisis tersebut kemudian dilakukan analisis lanjutan berupa overlay antar data untuk mengetahui persebaran dan pola lahan sawah. Integrasi analisis SIG, perubahan paradigma, dan metrik tutupan lahan dapat digunakan untuk mengetahui perubahan penggunaan lahan dan mengetahui besaran dampak yang dikarenakan urbanisasi (Song et al., 2015). Secara konsep pengolahan hasil analisis dapat dilihat pada Gambar 8.

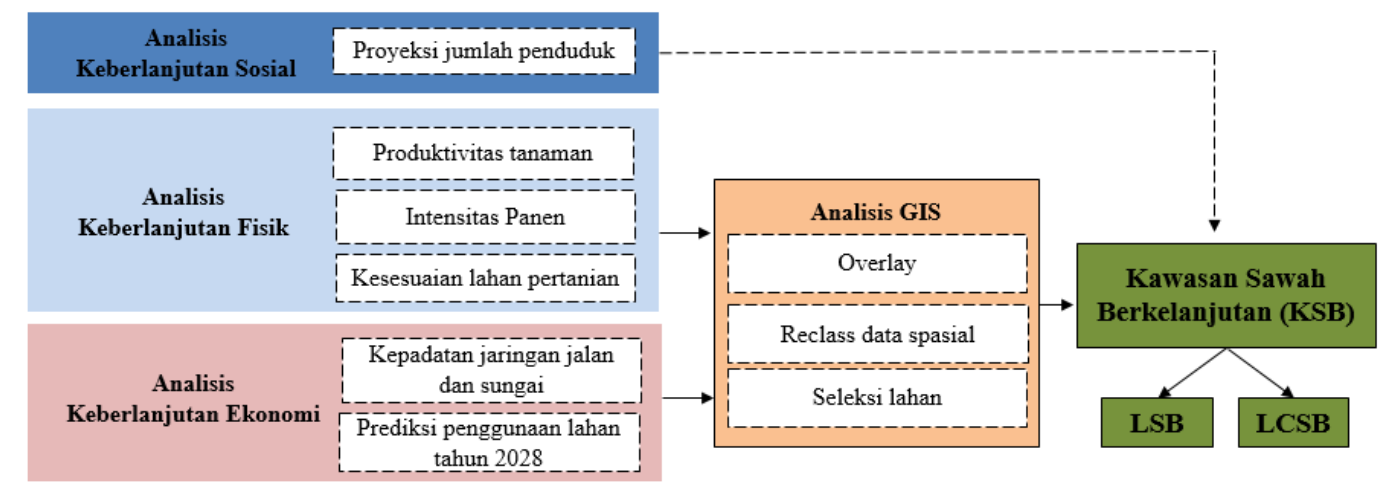

Sumber: Hasil Analisis, 2018

\section{Gambar 7. Konsep Pengolahan Analisis}

Berdasarkan analisis lahan sawah berkelanjutan diperoleh pembagian lahan berupa Lahan Cadangan Sawah Berkelanjutan (LCSB) dan Lahan Sawah Berkelanjutan (LSB). LCSB merupakan suatu lahan yang berupa sawah namun berpotensi alih fungsi lahan dan tidak memenuhi standar teknik luasan minimal (kurang $5 \mathrm{Ha}$ ). Sedangkan LSB merupakan lahan yang secara teknis sesuai untuk tetap dilestarikan keberlanjutannya. Prinsip penentuan LSB ini sudah memperhatikan prediksi lahan pada tahun 2028.

Gambar 8 menjelaskan tentang pemodelan keberlanjutan lahan sawah dan potensinya. Luas yang KSB sebesar 24.206,3 ha yang terdiri dari LSB seluas 22.562,46 ha dan LCSB seluas 1.643,84 ha. Pada peta tersebut menunjukan pola yang menyebar, namun secara spasial persebaran lahan sawah berada pada jaringan sungai dan sekitar Rawa Pening. Hasil penelitian berupa KSB tersebut dilakukan uji kesesuaian dengan rencana tata ruang baik berupa rencana tata ruang wilayah (RTRW) maupun kawasan pertanian pangan berkelanjutan (KP2B). Maka diperoleh hasil penelitian memiliki tingkat kesesuaian sebesar 94,5\% sesuai dengan RTRW dan $93,18 \%$ sesuai dengan $K P_{2} B$. 


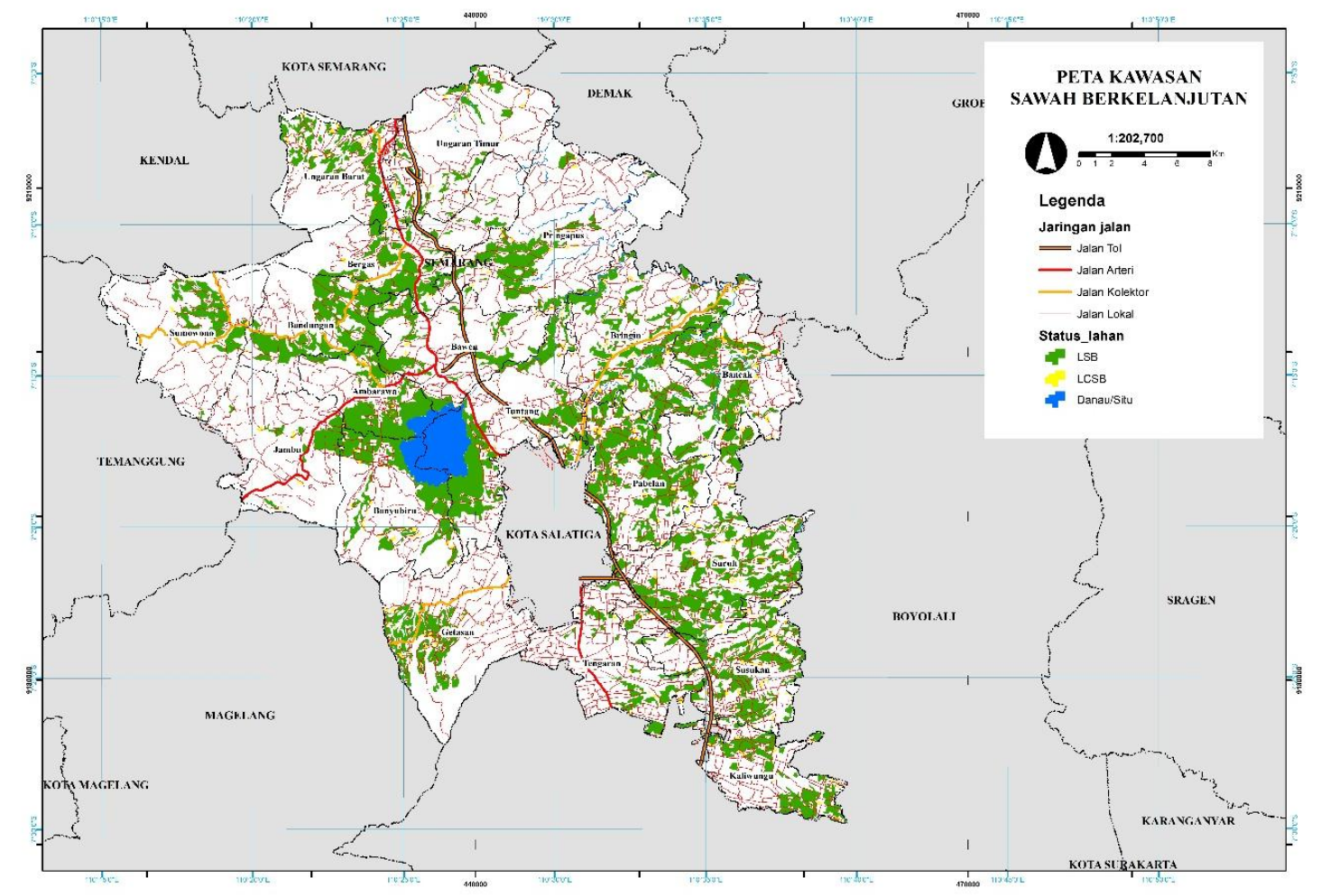

Sumber: Hasil Analisis, 2018

Gambar 8. Peta Kawasan Sawah Berkelanjutan

\section{KESIMPULAN}

Berdasarkan hasil penelitian ini, dapat disimpulkan bahwa kondisi lahan sawah di Kabupaten Semarang semakin terancam dari aspek keberlanjutannya. Terdapat 5 analisis dalam menyusun penelitian ini yang meliputi analisis produktivitas padi, kesesuaian lahan pertanian, intensitas panen, kepadatan jalan dan irigasi, serta prediksi penggunaan lahan. Hasil yang diperoleh menunjukan bahwa kawasan sawah berkelanjutan (KSB) Kabupaten Semarang seluas 24.206,3 ha. KSB tersebut terdiri dari lahan sawah berkelanjutan (LSB) dan lahan cadangan sawah berkelanjutan (LCSB). Terdapat 94,5\% sesuai dengan RTRW dan $93,18 \%$ sesuai dengan $\mathrm{KP} 2 \mathrm{~B}$.

Hasil penelitian menunjukan bahwa Kecamatan Ungaran Barat, Ungaran Timur, Bergas, dan Bawen merupakan kawasan yang terancam konversi lahan. Koversi lahan ini disebabkan karena adanya urbanisasi. Pemodelan KSB ini hanya sebagai alat dalam menentukan zonasi lahan. Penelitian ini sangat penting sebagai acuan dalam menentukan upaya perlindungan dan peningkatan produksi dalam kaitanya ketahanan pangan di Kabupaten Semarang.

\section{REFERENSI}

Ashidqi, I. S., \& Taryono, I. (2017). Analisis Estimasi Produksi Lahan Pertanian Padi di Kabupaten Brebes. Huang, J. (2015). Rice yield estimation using remote sensing and simulation model. ResearchGate, 3 No.4(2012), 461. https://doi.org/10.1007/BF02839491

Irawan, B. (2005). Konversi lahan sawah : potensi dampak, pola pemanfaatannya, dan faktor determinan. Forum Penelitian Agro Ekonomi, 23(1), 1-18.

Liaghat, S., \& Balasundram, S. . (2010). A Review : The Role of Remote Sensing in Precision Agriculture. American Journal of Agricultural and Biological Sciences, 5(1), 50-55.

Mas, J. F., Kolb, M., Paegelow, M., Camacho Olmedo, M. T., \& Houet, T. (2014). Inductive pattern-based land use/cover change models: A comparison of four software packages. Environmental Modelling and Software, 51, 94-111. 
Nafi, Basuki/ Jurnal Pembangunan Wilayah dan Kota, Vol.15, No.3, 2019

Doi: https://doi.org/10.14710/pwk.v15i3.21570

https://doi.org/10.1016/j.envsoft.2013.09.010

Mosleh, M. K., Hassan, Q. K., \& Chowdhury, E. H. (2015). Application of Remote Sensors in Mapping Rice Area and Forecasting Its Production: A Review. Sensors, 15(i), 769-791. https://doi.org/10.3390/s150100769

Naab, F. Z., Dinye, R. D., \& Kasanga, R. K. (2013). Urbanisation and its impact on agricultural lands in growing cities in developing countries: a case study of Tamale in Ghana. Modern Social Science Journal, 2(2), 256-287. Retrieved from http://scik.org/index.php/mssj/article/view/993

Nafi, ahmad yazidun, Suhairini, E., \& Sanjoto, tjaturahono budi. (2016). Estimasi Produktivitas Padi Menggunakan Teknikpenginderaan Jauh Dalam Mendukung Program Swasembada Pangan. Geo Image, 5(2), 1-7. https://doi.org/10.1371/journal.pone.0079965

Noureldin, N. A., Aboelghar, M. A., Saudy, H. S., \& Ali, A. M. (2013). Rice yield forecasting models using satellite imagery in Egypt. Egyptian Journal of Remote Sensing and Space Science, 16(1), 125-131. https://doi.org/10.1016/j.ejrs.2013.04.005

Panuju, D. R., Mizuno, K., \& Trisasongko, B. H. (2013). The dynamics of rice production in Indonesia 1961-2009. Journal of the Saudi Society of Agricultural Sciences, 12(1), 27-37. https://doi.org/10.1016/j.jssas.2012.05.002

Rahman, A., Goldberg, M., \& Niazamuddin, M. (2009). Use of Vegetation Health Data for Estimation of Aus Rice Yield in Bangladesh. Sensors, 9(September 2015), 2968-2975. https://doi.org/10.3390/s90402968

Raziq, A., Xu, A., Li, Y., \& Zhao, Q. (2016). Monitoring of Land Use / Land Cover Changes and Urban Sprawl in Peshawar City in Khyber Pakhtunkhwa : An Application of Geo- Information Techniques Using of Multi-Temporal Satellite Data. Journal of Remote Sensing \& GIS, 5(4), 174.

Santosa, S., Rustiadi, E., Mulyanto, B., Murtilaksono, K., Rachman, N. F., Ilmu, D., ... Bogor, D. (2014). Modelling on Development of Sustainable Paddy Field Zone Based on Logistic Regression and Multicriteria Land Evaluation at Sukabumi Regency. Globe, 16 No. 2(2013), 181-190.

Song, J., Cai, D., Deng, J., Wang, K., \& Shen, Z. (2015). Dynamics of Paddy Field Patterns in Response to Urbanization: A Case Study of the Hang-Jia-Hu Plain, 13813-13835.

Wahyunto, Widagdo, \& Heryanto, B. (2006). Pendugaan produktivitas tanaman padi sawah melalui analisis citra satelit. Informatika Pertanian, 15, 853-869.

Widiatmaka, Ambarwulan, W., Santoso, P. B. K., Sabiham, S., Machfud, \& Hikmat, M. (2016). Remote Sensing and Land Suitability Analysis to Establish Local Specific Inputs for Paddy Fields in Subang, West Java. Procedia Environmental Sciences, 33(April), 94-107.

Widiatmaka, Ambarwulan, W., Tambunan, R. P., Nugroho, Y. A., \& Santoso, P. B. (2014). Land use planning of paddy field using geographic information system and land evaluation in West Lombok, Indonesia. ljg, 46(1), 89-98. 